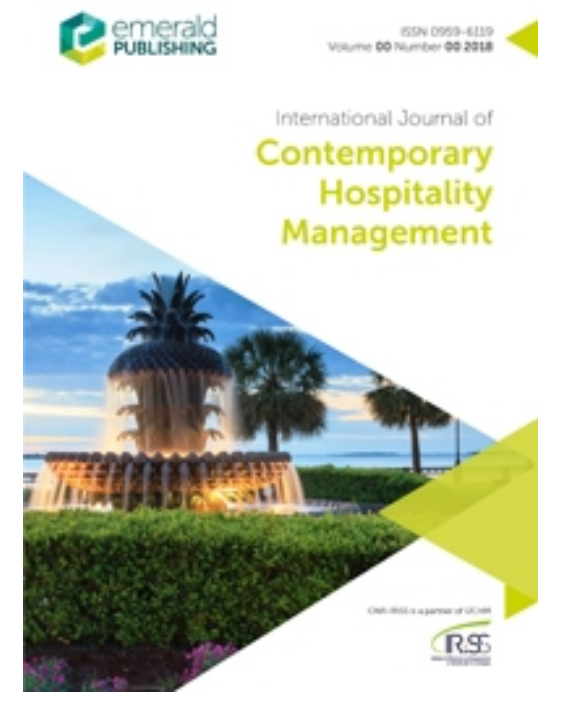

\title{
Conceptualising patterns of career commitment: the leaving process in hospitality
}

\begin{tabular}{|r|l|}
\hline Journal: & International Journal of Contemporary Hospitality Management \\
\hline Manuscript ID & Draft \\
\hline Manuscript Type: & Original Article \\
\hline Keywords: & $\begin{array}{l}\text { Career Development, Hospitality, Life History, Career Commitment, Self- } \\
\text { efficacy, Career Inheritance }\end{array}$ \\
\hline \multicolumn{2}{|l}{} \\
\hline
\end{tabular}

\section{SCHOLARONE Manuscripts}




\section{"Conceptualising patterns of career commitment: the leaving process in hospitality"}

\section{Abstract}

Purpose

This paper examines the interplay between self-efficacy and career inheritance, and its influence on career commitment in the hospitality sector. High labour turnover, unclear career paths and the transient nature of the work available in hospitality render it a suitable industry context that allows us to explore career commitment patterns.

Design/methodology/approach

Drawing on life history methodology, semi-structured interviews were conducted with hospitality professionals holding a relevant degree but no longer employed in the hospitality industry.

Findings

The findings revealed the interplay between self-efficacy, career inheritance and career commitment as well as the speed of decline of career commitment, visualised as patterns of the leaving process. Although an infinite number of variations are possible, data unveiled the three main patterns.

Practical implications

This newly conceptualised understanding of career commitment enables researchers to reconsider the fundamental reasons why individuals leave the hospitality industry, whilst also offering hospitality managers deeper insights in to how the three identified patterns could inform recruitment and selection.

Originality/value

This paper contributes to the literature through its meaningful theoretical extension in the context of career development studies. The unique concept of the leaving process addresses the prevalent issue of turnover and generates important implications.

\section{Keywords}

career development, hospitality, life history, career commitment, self-efficacy, career inheritance 


\section{Introduction}

Career requirements, associated with occupational meaning and career identity (Aryee et al., 1994; Cherian and Jacob, 2013), have shifted for the $21^{\text {st }}$ century employees. Career seekers work towards becoming lifelong learners, who can use sophisticated information technologies, choose flexibility over stability, and create work-related opportunities. As careers belong to the person rather than the organisation, occupational prospects are no longer easily definable or predictable (Duarte, 2004; Savickas et al., 2009). Individuals have to learn to self-manage their careers, and to adapt to changes caused by increased globalisation, pressure for productivity, changing and blurring of industries and jobs, to name a few (Weiss et al., 2003; Amundson, 2005; Sullivan and Baruch, 2009). Such career complexities have recently become evident in the rapidly changing work environment of the hospitality industry, characterised by its fast-changing and adaptable nature (WTTC, 2017; British Hospitality Association 2018). The industry, a leading generator of income, plays a significant role in creating new jobs both, in a region and within minority groups (Casado-Díaz and Simón, 2016; Salihoğlu and Gezici, 2018). However, the hospitality and tourism sector needs to recruit $1.3 \mathrm{~m}$ staff by 2024 , as approximately 365,000 staff leave the sector every year, which accounts for $20 \%$ of the sector's total workforce (People $\left.1^{\text {st }}, 2017\right)$.

A significant body of academic research supports the hospitality industry statistics indicating a low retention rate. According to King et al. (2003), 48\% of the respondents left the hospitality industry within 3-5 years after graduating. In another study (O'Leary and Deegan, 2005 ) only $48 \%$ of hospitality graduates remained in the industry and $68 \%$ moved jobs at least once. According to Johns and McKechnie (1995) and Barron et al. (2007), only half of hospitality graduates have chosen a career in that industry in the UK. In contrast, a longitudinal research by Walsh and Taylor (2007) identified that almost $54 \%$ of hotel administration graduates worked directly in the industry, owing high retention rate to challenging work, new skills development and promotional opportunities (Walsh and Taylor, 2007). High retention rates of Generation $Y$ hospitality graduates can be attributed to enjoyable work and exciting and challenging career, whereas long hours and poor compensation as reasons for leaving (Brown et al., 2015).

The hospitality industry is known for the transient nature of its work and unclear career paths (Baum, 2015). However, the concept of career has shifted towards agency and career self- 
management (Akkermans and Kubasch, 2017) offering opportunities for professional development beyond the boundaries of an employing organisation.

This paper aims to gain insights into career trajectories of ex-hospitality professionals with a view of understanding why they left the hospitality industry by drawing on three interdisciplinary concepts - career commitment, career inheritance and self-efficacy. Khapova and Arthur (2011) urge towards an interdisciplinary inquiry into careers, while Akkermans and Kubasch (2017) argue for research on specific career paths of certain target groups.

\section{Theoretical Background}

On the topic of turnover and retention, Rehman and Mubashar (2017) identified factors which influence turnover intentions, and these are individual variables, both personal/ demographic and occupational ones, organizational variables, such as pay, promotion, and policies, external environment and attitudinal variables such as job satisfaction and organisational commitment. Better training and development programmes, and managing work-life balance are necessary factors to ensuring high employee retention in the hospitality industry (Deery and Jago, 2015). Appropriate levels of pay and career opportunities have also been cited, alongside training, empowerment and rewards (Karatepe, 2013), better career advancement opportunities and employment conditions (Yang et al., 2012). The perceived negative image of the industry, known for its seasonality and casual contracts, has been also an issue for staff retention (Wildes, 2005; Hausknecht, et al. 2009; Deery and Jago, 2015). The dominant labour supply strategy based on casual contracts implies that individuals have little protection in law, are paid the national minimum wage, and are less likely to be committed to the organisation or the industry altogether (Davidson et al., 2010). This "just in time" approach to changing demand for human resources makes it challenging for the industry to establish long-term employment relationships (Horng and Lin, 2013: 61).

The following sections examine the concepts of career commitment, career inheritance and self-efficacy, as key to understanding the complexities of career-decision making.

\section{Career commitment}

Commitment is a complex and multifaceted construct, conceptualised as either unidimensional or multidimensional and lacking in an agreed definition. The antecedents, correlates and consequences of commitment vary across dimensions (Meyer et al., 1993; 
2002). Individuals can be committed to economic, educational, familial, political and vocational factors at the same or different times (Vance, 2006). Commitment can be also manifested in distinct behaviours and people who demonstrate high commitment may be given the most favourable work assignments (Arnold, 1990). Despite significant research attention on the subject of commitment, historically the work on career commitment has received the least consideration (Aryee and Tan, 1992; Meyer et al., 1993; Goulet and Singh, 2002). Due to the shifting nature of career, career commitment is considered "an affective concept which represents identification with a series of related jobs in a specific field of work and is behaviourally expressed in an ability to cope with disappointments in the pursuit of career goals" (Aryee and Tan, 1992: 289). The ability to cope with disappointments whilst pursuing career goals allows the linking of career commitment with self-efficacy.

Originally, commitment was conceptualised in relation to organisations as the threecomponent model of commitment (Meyer and Allen, 1984; Meyer et al., 1993). In this paper, the model is applied to understanding career commitment (Meyer et al., 1993; 2002). Affective commitment, or the mindset of desire, develops when an individual derives his or her identity from a career having had a satisfying experience, and is the strongest dimension of commitment (Meyer et al., 1993; Meyer and Herscovitch, 2001). Continuance commitment, or the mindset of perceived cost, arises under two conditions: when one realises that the investment made is greater than the possibility of leaving; or when there are no other options available but to continue in the chosen career. Normative commitment, or the mindset of obligation, develops through socialisation of norms (Meyer and Herscovitch, 2001). Challenging work experience, positive professional development experiences, supportive organisational environment, interesting work (Sullivan et al., 1998), and the inner characteristics of an individual, such as self-worth and resilience (Goulet and Singh, 2002) enhance the levels of career commitment.

\section{Career inheritance}

Having a family with a long career history can contribute to the normative commitment, which is linked to career inheritance, a multi-faceted concept (Inskon, 2004). Its main principle is that careers are inherited from the family into which one is born, and family occupations and socio-economic status shape pre-career childhood experiences and expectations (Inkson, 2004). This concept considers an individual's past and the influence of significant others, and 
how they have shaped one's life and career (Fouad et al., 2016). Recognising the structure and agency dichotomy, Inkson (2007) argues that a lack of equality within society means people's choices are often inhibited by structural constraints, and they struggle to become proactive agents of their career choices. Knowledge of one's career inheritance should empower the decision-maker to either accept or reject this legacy (Inkson, 2004), which will promote a more proactive career behaviour.

The conceptual basis of career inheritance is drawn from a study by Goodale and Hall (1976), where parents, as role models, played a significant role for students who were deciding about their college and career plans. The theoretical foundations of this concept are based on the Gottfredson's (2002) theory of circumscription, compromise and self-creation. The choice of a career is a developmental process, which commences in childhood (Gottfredson, 1996). As children grow in awareness of themselves and their social place, vocational options are eliminated if incompatible with their evolving self-image (Gottfredson, 2005; Swanson and Fouad, 2010). Critical to the development of self-concept is advancing through the five stages of circumscription, during which an individual begins to implement career decisions based on their suitability or their relation to internal self (Patton and McMahon, 2006; Leung, 2008). Compromise - giving up a preferred alternative for that which is more accessible - is concerned with recognising existing opportunities and barriers in the social and economic environment that influence the chances of acquiring a particular occupation (Gottfredson, 1981: 548). Through the processes of circumscription and compromise, individuals are able to self-define and self-create themselves, because of the perceived limited choices of available paths (Patton and McMahon, 2006). Individuals' efforts to apply their self-concepts are reflected in their career aspirations, while satisfaction with a career choice is based on how well it fits the self-concept. As one's self-knowledge deepens, individuals begin to take charge of their own lives, rather than take on a passive role of observers (Gottfredson, 1996).

\section{Self-efficacy}

As career inheritance resembles the structure, self-efficacy is a more powerful factor to structure in guiding people's actions (Bandura, 1995). Assuming a significant ability and freedom to overcome the constraints of one's career inheritance, having strong beliefs in one's capabilities will help to persist in chosen pursuits (Sewell, 1992). Perceived self-efficacy "refers to beliefs in one's capabilities to organize and execute the courses of action required 
to manage prospective situations" (Bandura, 1995: 2), and is central to the social cognitive theory (SCT), which favours the emergent form of agency. High self-efficacy is likely to lead to increased performance and productivity (Cherian and Jacob, 2013), higher levels of career commitment (Chung, 2002; Niu, 2010), and to 'approach versus avoidance behaviour', critical to understanding career commitment (Betz and Hackett, 2006). Employees become more motivated to pursue self-realisation, are committed to their careers and learn voluntarily (Bandura, 1997; Niu, 2010).

The self-knowledge about one's efficacy can be developed and modified through four sources (Bandura, 1977; 1986; 1998). Previous accomplishments are the most influential source of self-efficacy (Bandura, 1998), because success achieved on one's own is more meaningful than that achieved with help from others (Usher and Pajares, 2008). Self-efficacy can also be influenced by observing and modelling one's own behaviour on successful others, such as social models (Bandura, 1977; 1986; 1995; 1998). Encouragement and verbal persuasion also increase beliefs in one's own capabilities, (Bandura, 1986; 1995), whereas mentoring and coaching help to develop positive attitudes and career capital (Akkermans and Kubasch, 2017). Finally, physical and emotional states enable people to judge their capabilities, strength, vulnerability to dysfunction, and learn how to act on them to achieve the most desired outcomes (Bandura, 1986; 1997). Self-efficacy has a wide application across many academic disciplines, but the power of efficacy beliefs to influence life paths is most visible in studies into career choice and development (Lent et al., 1994) and is strongly supported in the literature (cf. Hackett, 1995; Betz and Hackett, 1997; 2006; Betz, 2000). Self-efficacy, one of the four factors of positive psychological capital, was found to be negatively related with job stress which in turn is positively related with the turnover intentions (Choi and Kim, 201; Rehman and Mubashar, 2017).

\section{Research Design}

In the literature examined the three interdisciplinary concepts are indeed influential on one's decision to leave the hospitality industry. Neither does the literature consider how they interact with each other, if at all. This paper aims to illuminate this possible interaction by analysing rich interview data provided by hospitality graduates, no longer employed in the hospitality industry. 
The researcher adopted a flexible approach to data collection, designed to bring out themes related to career commitment, career inheritance and self-efficacy (Miller, 2000) and with a view to standardising the interview process. To achieve this, this research draws on principles of life history- the historical categorisation of individuals' events and career stories (Goodson and Phillimore, 2004), which involves analysing one's 'life as a whole' (Atkinson, 2002; Ladkin, 2004). The individual's retrospective memories became "a window onto broader social and societal conditions" (Cole and Knowles, 2001: 12).

To achieve a holistic picture of each participant's life history, interview questions were designed to reveal information that covered the totality of participants' career choices. The interview questions also focused on different periods in participants' lives, including childhood and time of growing up, and were not asked in the same order during each interview.

Purposive sampling was used to select individuals who could purposefully inform the research problem (Warren, 2002). To bound the sample and to provide insights relevant for the hospitality industry in the United Kingdom (Creswell, 2007), hospitality management graduates, no longer employed by the hospitality industry, form the chosen population. This population is identified as under researched; the focus so far has been on understanding hospitality students' and graduates' career expectations and paths (McKercher et al., 1995; King et al., 2003; O'Leary and Deegan, 2005; Barron et al., 2007; Richardson, 2009; Chuang and Dellmann-Jenkins, 2010; Harkison et al., 2011).

\section{Selection of Participants}

Participants were recruited through personal contacts of the researcher, posts on social media sites - LinkedIn and Facebook, using the third party - the Council for Hospitality Management Education, as well as through the alumni departments of the University of Brighton and the Dublin Institute of Technology.

Seventeen life histories were collected. Out of 17 participants, 14 completed an undergraduate degree in hospitality management, two an undergraduate degree in tourism management, and one an undergraduate degree in communication arts. Those same three participants also completed a postgraduate degree in hotel and restaurant management. There was a clear disparity between the number of years spent working in the hospitality industry- from one year up to 18 years, including part-time and full-time employment. 
Placement year and work experience in the industry during the degree were also counted into the total number of years of employment in the hospitality industry. Only four participants had not worked in the industry before enrolling on a degree course. The detailed profiles of participants can be found in Appendix 1.

\section{Data analysis}

Interviews were transcribed verbatim and anonymised, and analysed using Braun and Clarke's (2006) six phases of thematic analysis. Attride-Stirling's (2001) thematic network analytic tool was used to identify global, organising and basic themes. Each global theme, pre-assigned in accordance with the three key concepts, consisted of further organising and basic themes. These emerged directly from the data. The initial stage of coding the pre-assigned themes was driven by the researcher's prior theoretical understanding of the three concepts (Ryan and Bernard, 2003). The qualitative data analysis computer software, NVivo, was used to organise and code all the interview data into the appropriate themes (Bazeley and Jackson, 2013). The basic and organising themes were continually reviewed; the coded sentences were either assigned to the existing themes or reconsidered. Once each interview had been coded, the basic and organising themes were reviewed again. At the point where no new information was revealed from the interviews, it was concluded that data saturation was reached (Saunders et al., 2018).

\section{Results}

\section{Career commitment: a developmental process}

Informing the process of leaving the hospitality industry is career commitment, described as the psychological contract between the individual and a chosen career. The findings confirmed that commitment is maintained reciprocally, in other words career commitment needs to bring desired benefits, whether economic, social, psychological or emotional (Cropanzano and Mitchell, 2005; Vance, 2006). Lack of any repayment for the act of committing contributes to the intention to leave:

"if the company I am working for recognises that I do a really good job and they are willing to move me up and keep me in the company, keep me motivated, that is what l appreciate" (Milly, 26)

The strength of commitment to the hospitality industry is influenced by the completion of a hospitality management degree and, in particular, at what point in participants' hospitality 
journey the degree was undertaken. Participants were motivated by different reasons to complete the degree. Those with some years of industry experience wanted to improve their future career prospects, yet those with little or no prior experience were motivated by the possibility of establishing themselves in the industry, because the degree was believed to open doors to managerial positions:

"if I wanted to get any kind of success within the industry, the high levels of management, you need to have at least a minimum of a bachelor degree" (Mark, 43)

"I loved the whole experience of university, the learning experience, the opportunities, the different people" (Louise, 27)

Therefore completing a degree was considered as a necessary step to improving their career prospects, or as explained by Sarah (31) "the next stepping stone".

Yet, contributing to the waning of career commitment was also the lack of reciprocation for a completed hospitality management degree. Because of the potentially high opportunity costs associated with undertaking the degree, graduates expected high returns on that investment in the form of better career opportunities and higher salary, as evidenced by the data. Participants talked about insufficient career opportunities for the time and effort they spent acquiring a degree:

"there were days I was there 8 days a week... I can't do this any more hence one of the reasons why I left, I've got 2:1 hotel degree, I am not putting up with this " (Joanna, 24)

"my father paid so much money for me to invest into my undergrad, why did I want to work for 20,000 a year at that time, I think I had too many aspirations and ambitions" (Anna, 30)

Although a significant number of participants gave direct reasons for exiting the industry, such as low monetary rewards, demanding and unsociable working hours and difficulties planning ahead due to shift work (cf. Duncan et al., 2013), these factors are considered only as partial reasons which contributed to the decision to leave. Career turning points, also referred to as critical organisational leverage points (Hall, 2004) and epiphanies what (Denzin, 1989), are important triggers that guide individuals' career decision-making processes and are critical to making the decision to leave. The data revealed that a career turning point, or a string of events that precede such a point, has significantly influenced the majority of participant's careers: 
"a day centre manager went behind my back and wanted to go back to the five day week rotational menu (...) he just made my life extremely difficult; he was the final nail on a coffin to say right, enough is enough, move on" (Monica, 40)

"it's a combination of major things, my last seasonal job at the restaurant... I just realised I was already tired of this...you don't have a life...plus the job was not getting gratifying or just respectful" (Jane, 22)

"I always promised myself, I wanna have a career, I love the hospitality industry, but I'm not willing to pay with my friends, with my family, and with my own health, and this is what just happened" (Claudia, 26)

"when I realised that the guy washing dishes was earning more money than me, I was an F\&B manager" (Mark, 43)

These career turning points are categorised as self-initiated and contribute to career identity transformation (Hodkinson and Sparkes, 1997). A person undergoing such an experience is likely to consider choosing to change a job within the same career, develop coping strategies when leaving is not an option, or decide to change career altogether. The latter was an option chosen by participants, who were no longer able to cope with the disappointments of a career in the hospitality industry. Also called 'career leavers' (Blau, 1989), they left the hospitality industry in search of better employment opportunities in non-hospitality sectors.

\section{Career inheritance: the legacy of hospitality}

Within the context of hospitality, career inheritance is expressed as the legacy of hospitality. Participants, who showed high levels of career inheritance, were born into a family directly linked with the hospitality industry. In this instance careers were inherited from one of the parents. Participants were prepared to work in the industry for longer, before they made the decision to leave:

"my father was a hotelier, my grandfather, great-grandfather so it's family tradition (...) I was born in the hotel, grew up in the hotel, never really envisaged doing anything else" (Mark, 43)

"when she (mother) managed pubs and we live in them, everyone just looked like they were having fun and relaxing, and to me it was a nice environment to be in" (Louise, 27)

Such individuals also experienced a strong emotional attachment to the all-encompassing philosophy of hospitality, identified as taking care of other people to the extent that they feel relaxed physically, mentally and/or emotionally. As hospitality can be experienced in different 
social settings, it is not bound to a specific work environment, but is universally applicable to other social settings:

"even at a friend's house, when I have friends over I'm providing hospitality; you don't just go to a hotel and get it, it's everywhere" (Louise, 27)

"making people feel that they're welcome within a certain space, albeit whether it's in your home or in a canteen or in a café, I think hospitality happens wherever you go" (Monica, 40)

Understood as an affective form of commitment (cf. Meyer et al., 1993), the legacy of hospitality implies that despite leaving the hospitality industry, individuals desire to implement the philosophy of hospitality in non-hospitality roles. Welcoming attitude and environment, and meeting guests' needs, are considered key characteristics of an organisation wide philosophy of hospitality in hospital settings (Severt et al., 2008). This means that hospitality values continue being applied in other sectors outside the hospitality industry.

The philosophy of hospitality allows individuals to practise hospitality and fulfil their passion for being hospitable - a characteristic which Telfer (2000) considers part of the term hospitableness. Participants, who self- identify as hospitality people, feel the need to share their homes and their provisions with others in an act of hospitableness. Identifying with hospitality becomes a significant part of one's entire life:

"once you've been in the industry, you never leave the industry, because it's always a part of you, there is always a hospitality thing about you, if you are a hospitality person, you're hospitality person" (Sarah, 31)

The distinction between commitment to the philosophy of hospitality and commitment to the hospitality industry is seen in Jane's recent career change, which also shows that the legacy of hospitality is boundaryless:

"in the navy they will offer me this kind of relationship but the true one, without the money; I would get to cook and serve food for people who would not be demanding and I would not ask for money" (Jane, 22)

\section{Career manager: a self-efficacious agent of change}

Together with career inheritance, the concept of self-efficacy influences the process of leaving the hospitality industry, which is informed by career commitment. Thus, self-efficacy allows 
for a better understanding of the nature and characteristics of the career manager, a selfefficacious agent of change responsible for career self-development who believes in their capabilities to achieve desired results. The decision to leave the hospitality industry is based on feeling capable to find employment opportunities elsewhere by capitalising on already mastered skills. Thus, self-efficacy was the foundation for making self-determined career decisions:

"You're there to be a problem solver, and decide what you gonna do; always been a confident person, to take charge of other people (Jack, 29)

"as I do every year I asked myself what do you wanna change in your life, so at 39, I finished with this hotel catering business and I quit" (John, 56)

Individuals with powerful self-efficacy relied on themselves to achieve desired careers, had confidence in their own capabilities, took control of their career choices, and focused on selfdevelopment. These capabilities were driven by the feeling of self-confidence derived from four sources of self-efficacy (cf. Bandura, 1977; 1986): successful past performance:

"I know how to serve, how to work the till systems, how to do a stock control and I knew that doing a simple cafe or restaurant job is something pretty much the same to what I used to do before, so this kind of experience gave me all this confidence" (Claudia, 26)

the confidence when I started to when I finished, I was a different person, I believed in myself a lot more; if I could finish a degree I could finish everything" (Louise, 27)

Support and encouragement from others was another source of self-efficacy, such as receiving positive feedback and words of encouragement:

"I sit in my comfort zone, I need someone to say 'you can do that position', to look at the skills that you've got, and you can do it, but I find it quite hard to sell myself, I don't want to get arrogant" (Sarah, 31)

Physical and emotional states enabled a career manager to turn negative experiences into positive ones and treat them as challenges to be overcome:

"I think every day is a various challenge in life, I just have to be aware that they are coming, and you have to deal with them" (Anna, 30)

"I think you learn by trial and error sometimes. So if I have to do it, I will do it, if I fail, I fail and I learn from it" (Joanna, 24)

A career manager took charge of career decisions by remaining fully informed about available career choices, and recognised his or her changing career preferences. Career managers 
would embrace change, and had the capabilities to recover from challenging activities by treating them as tasks to be mastered:

"there is other roles out there I could possibly do, I could try and support people in a different way and potentially earn more money" (Monica, 40)

"I'm getting stressed about something, which I can change. I couldn't change what I was doing in my job (...) time for me to think about moving on" (Sarah, 31)

\section{Discussion}

\section{The leaving process}

Career commitment, career inheritance and self-efficacy were proposed as the three key concepts whose possible interaction could provide insights into the process that led hospitality professionals to exiting the hospitality industry. The unique interaction between these concepts emerged from the data and becomes the basis for the concept of the leaving process.

The findings revealed that the initial decline in commitment is influenced primarily by the working conditions in the hospitality industry or lack of reciprocation for having a hospitality degree. The speed of decline in commitment that follows, or the rate of change in commitment, is dependent on the interaction between career inheritance and self-efficacy. The interplay between these three concepts can be visualised as patterns of the leaving process, and although an infinite number of variations are possible, data unveiled the three main patterns. Each pattern will be explained separately.

The leaving process PATTERN 1, depicted in Figure 1. as a purple convex line explains that leaving the hospitality industry is not based on an impulse but instead is a dynamic process punctuated by career turning point(s). Once the decision to leave is made, the speed of decline in commitment, influenced by high self-efficacy and low career inheritance, is rapid. Professionals who fall into this category exhibit characteristics of a career manager, informed by principles of self-efficacy. Such individuals make self-determined career decisions and prioritise career opportunities over job commitment.

Figure 1. The leaving process PATTERN 1 
The leaving process PATTERN 2, a blue concave line, demonstrates that although the initial decline in commitment is rapid, it is followed by a steady decrease which concludes with a professional leaving the industry. The individual experiences an affective commitment to the philosophy of hospitality founded on the concept of career inheritance, whilst the level of self-efficacy is low. Such an interaction between these two concepts delays the decline in commitment. As a result the level of career inheritance is higher than that of self-efficacy.

Figure 2. The leaving process PATTERN 2

Professionals who represent the leaving process PATTERN 3 experience a steady and consistent decline in commitment, and exhibit characteristics of a career manager. The duration of employment and the level of job commitment are strongly dependent on the career growth potential and overall employability prospects. Therefore, the decision to leave the hospitality industry is a process represented by shifting away from core hospitality roles into more generic ones. When all the perceived benefits are gained, the individual chooses to leave to further enhance employability prospects and increase future career opportunities.

Figure 3. The leaving process PATTERN 3

Therefore, conceptualised as part of a larger career decision-making process, the decision to leave the hospitality industry is seldom a single event made in isolation (Hodkinson, 2008), but rather there is a string of events that precede it. Following the developmental route of career research employed in this study (Gottfredson, 2002, 2005; Patton and McMahon, 2006) and revealed in the findings, making a career choice is perceived as a process rather than an event. Therefore, the concept of the leaving process is a complex journey punctuated by significant career turning points that led to participants' decision to leave the hospitality industry. The dynamic, flexible and non-linear nature of career paths contributes to making this decision, because individuals no longer feel bound to an organisation or an industry for a specific period of time (Collin and Young, 2000; Weber and Ladkin, 2008; Sullivan and Baruch, 
2009), and instead develop commitment to their careers. The research findings revealed that the decision to leave the hospitality begins with a waning of job commitment triggered by significant career turning points as illustrated in the above three figures. Thus the concept of the leaving process is developmental in nature, in line with the principles of career commitment, and further underpinned by a unique interaction between self-efficacy and career inheritance.

As previously stated, there are an infinite number of variations of the leaving process. To demonstrate an example of one of the very many possible variations, the red linear line was added to the schematic illustration in Figure 4. This line represents a different possibility of the leaving process PATTERN 3. The shape of this line helps to explain that the decision to leave can be based on an impulse. In such an instance the individual experiences a career turning point, which causes a very rapid decline in commitment. A negative placement work experience or a challenging first year of employment in the hospitality industry can have a significant, negative impact on the choice not to pursue a career in the industry or leave after a very short period of employment. Research confirms that internship opportunities allow students to develop a more accurate picture of the industry and their career expectations (Ko, 2007; Kim et al., 2010; Brown et al., 2016).

Figure 4. The Leaving Process

\section{Conclusions}

This paper provides insights on career trajectories of hospitality professionals with a particular focus on the process behind their decisions to leave the hospitality industry. The unique interaction between career inheritance and self-efficacy, and their relationship with career commitment, shed light on the concept of the leaving process, the original contribution of this research.

The research findings revealed that career commitment is a developmental process and informs and underpins the concept of the leaving process. This unique approach to understanding the process is significantly influenced by critical career turning points, which 
are important moments in individuals' careers that transform the intention to leave into the decision to leave, and help to illustrate that leaving a job in the industry is a shifting process (Hall, 2004; Hodkinson and Sparkes, 1997). Employed as a conceptual foundation for the process of leaving the industry, career commitment further helps to explain that as individuals go through this process, their focus begins to shift away from the job and to one's career. The decline in commitment to the industry occurs in exchange for growing commitment to one's career. Therefore, the decision to leave the hospitality industry starts with the waning of job commitment, followed by the increase in career commitment. The leaving process does not reflect organisational procedures that individuals follow when they leave a job, such as handing in a letter of resignation. Neither does it imply that individuals have no choice in the matter of leaving. Instead, this process is highly subjective and requires a high degree of confidence to make a decision to leave. Completing the leaving process requires commitment to the self, which is evident in one's commitment to career choices, having clarity about future career goals, and a strong sense of confidence in one's own capabilities.

Based on the research findings, three patterns of the leaving process were identified, namely PATTERN 1, 2 and 3, although there are an infinite number of variations of these patterns. Different interactions between career inheritance and self-efficacy support each of the patterns and the impact on their interplay on career commitment. Each of the patterns is founded on the premise that individuals with high self-efficacy and low career inheritance would leave the industry sooner than those with low self-efficacy and higher career inheritance. PATTERN 1 demonstrates that once the decision to leave the industry is made, it is followed by a rapid decline in commitment influenced by high self-efficacy and low career inheritance. The leaving process PATTERN 2 illustrates that although the initial decline in commitment is rapid, it is followed by a steady decline due to higher levels of career inheritance than self-efficacy. PATTERN 3 is characterised as a shifting process during which the individual, referred to as a career manager with high self-efficacy, moves away from core hospitality roles into more generic one's, and slowly transitions themselves away from the industry. The three patterns of the leaving process are of particular significance as they demonstrate new insights on career decision-making as a developmental process. This newly conceptualised understanding of career commitment enables researchers to reconsider the fundamental reasons why individuals leave the hospitality industry. On the other hand, 
hospitality professionals may benefit from the deeper understanding of these patterns which could inform the recruitment and selection.

In order to utilise the concept of the leaving process, a self-help tool is proposed, which will allow career managers to map out career steps and goals, and alert them when a career decision needs to be made. As identified in this research, critical career turning points have the power to transform an intention to leave into a decision to leave. Therefore this tool will incorporate such turning points, and the sources of self-efficacy, and enable career managers to reflect on their past experiences with a view to incorporating them into future career planning. This will also enable hospitality businesses to play a significant role in ensuring that employees' career needs are met, and that they remain committed to their careers. This employee-driven approach to career management can be further collaborated with the organisational objectives, and provide mutual benefits for both, hospitality employees and businesses.

This paper contributes to the literature through its meaningful theoretical extension in the context of career development studies. The unique concept of the leaving process addresses the prevalent issue of turnover and generates important academic and practical implications.

\section{Limitations}

Retelling career stories is highly subjective, whereas retrospective accounts pose a number of biases, such as difficulty of recalling stories and the possibility of forgetting important events or adding new facts. Only one interview with each participant was conducted. The purposive sampling was not representative of the entire population of the hospitality management graduates, and thus the results are not generalisable. The schematic illustrations of the patterns of the leaving process are only visual representations of the research findings and are not representative. Although the chosen research design provided a view on careers at a specific point in participants' lives, this may have implications related to participants providing a one-sided and, perhaps, more negative view of the industry fuelled by a significant life event. Also some participants had only recently left the hospitality industry, which could have increased their willingness to share their feelings and opinions.

\section{Future Research}

To standardise the leaving process, future research should employ the current research design and the conceptual framework in other service sectors using a larger sample 
population. A social database could be used to conduct a network analysis to research individuals' entire career paths, including number of employers and types of jobs performed. This may provide a more detailed analysis of factors that impact on the duration of leaving such the working environment or a lack of degree. This will validate the leaving process as a conceptual tool applicable in other settings. The paper focused on why hospitality graduates left the industry. Future research should interview employees and managers who did not study hospitality but worked in the industry for a period of time and decided to leave. The leaving process was founded on the interaction of career commitment, career inheritance and self-efficacy. Future research should explore other variables that might contribute to an even greater understanding of the leaving process and strengthen it theoretically. Due to the uniqueness and originality of the concept of the leaving process, further research is required to shed light on adequate managerial tools that could help to slow down or prevent the leaving process. Within the HRM literature, the focus has been directed towards collective turnover (Hancock et al., 2017) and how individuals' career decisions impact on their colleagues and the overall organisation performance, which is considered another avenue for future research. Finally, this research focused on the individual's perspective of career management and career decision-making. Future research should consider organisational needs and societal trends, such as talent management or employment shortages.

\section{References}

Akkermans, J. and Kubasch, S. (2017), "\#Trending topics in careers: a review and future research agenda", Career Development International, Vol. 22 No. 6, pp. 586-627.

Amundson, N. (2005), "The potential impact of global changes in work for career theory and practice", International Journal for Educational and Vocational Guidance, Vol. 5 No. 2, pp. 91-99.

Arnold, J. (1990), "Predictors of career commitment: A test of three theoretical models", Journal of Vocational Behavior, Vol. 37 No. 3, pp. 285-302.

Aryee, S., Chay, Y.W. and Chew, J. (1994), "An investigation of the predictors and outcomes of career commitment in three career stages", Journal of Vocational Behavior, Vol. 44 No. 1, pp. 1-16. 
Aryee, S. and Tan, K. (1992), "Antecedents and outcomes of career commitment", Journal of Vocational Behavior, Vol. 40 No 3, pp. 288-305.

Atkinson, R. (2002), "The life story interview", in Gubrium, J.F. and Holstein, J.A. (Eds.), Handbook of Interview Research: Context and Method, Sage, Thousand Oaks, pp. 121-140.

Attride-Stirling, J. (2001), "Thematic networks: An analytic tool for qualitative research", Qualitative Research, Vol. 1 No. 3, pp. 385-405.

Bandura, A. (1977), "Self-efficacy: Toward a unifying theory of behavioral change", Psychological Review, Vol. 84 No. 2, pp. 191-215.

Bandura, A. (1986), Social Foundations of Thought and Action: A Social Cognitive Theory, Prentice-Hall, Englewood Cliffs.

Bandura, A. (1995), "Exercise of personal and collective efficacy in changing societies", in Bandura, A. (Ed.), Self-Efficacy in Changing Societies, Cambridge University Press, Cambridge, pp. 1-45.

Bandura, A. (1997), "Self-efficacy", Harvard Mental Health Letter, Vol. 13 No. 9, pp. 4-7.

Bandura, A. (1998), "Personal and collective efficacy in human adaptation and change", in Adair, J.G., Belanger, D. and Dion, K.L. (Eds.), Advances in Psychological Science Vol. 1: Personal, Social and Cultural Aspects, Psychology Press, Hove, pp. 51-71.

Barron, P., Broadbridge, A., Maxwell, G. and Ogden, S. (2007), "Careers in hospitality management: Generation Y's experiences and perceptions", Journal of Hospitality and Tourism Management, Vol. 14 No. 2, pp. 119-128.

Baum, T. (2015), "Human resources in tourism: Still waiting for change? - a 2015 reprise", Tourism Management, Vol. 50 No. 4, pp. 204-212.

Bazeley, P. and Jackson, K. (2013), Qualitative Data Analysis with NVivo, 2nd Edition, Sage, London.

Betz, N.E. (2000), "Self-efficacy theory as a basis for career assessment", Journal of Career Assessment, Vol. 8 No. 3, pp. 205-222.

Betz, N.E. and Hackett, G. (1997), "Applications of self-efficacy theory to the career assessment of women", Journal of Career Assessment, Vol. 5 No. 4, pp. 383-402. 
Betz, N.E. and Hackett, G. (2006), "Career self-efficacy theory: Back to the future", Journal of Career Assessment, Vol. 14 No. 1, pp. 3-11.

Blau, G. (1989), "Testing the generalizability of a career commitment measure and its impact on employee turnover", Journal of Vocational Behavior, Vol. 35 No. 1, pp. 88-103.

Braun, V. and Clarke, V. (2006), "Using thematic analysis in psychology", Qualitative Research in Psychology, Vol. 3 No. 2, pp. 77-101.

Brown, E.A., Thomas, N.J. and Bosselman, R.H. (2015), “Are they leaving or staying: A qualitative analysis of turnover issues for Generation $Y$ hospitality employees with a hospitality education", International Journal of Hospitality Management, Vol. 46, pp. 130137.

Brown, E.A., Bosselman, R.H. and Thomas, N.J. (2016), "Are hospitality graduates making too many compromises? What they give up may lead to turnover", Journal of Human Resources in Hospitality and Tourism, Vol. 15 No. 2, pp. 133-146.

British Hospitality Association (2018), "Who we are", available at: http://www.bha.org.uk/ (accessed 7 June 2018).

Casado-Díaz, J.M. and Simón, H. (2016), "Wage differences in the hospitality sector", Tourism Management, Vol. 52, pp. 96-109.

Cherian, J. and Jacob, J. (2013), "Impact of self-efficacy on motivation and performance of employees", International Journal of Business and Management, Vol. 8 No. 14, pp. 80-88.

Choi, K. and Kim, D-Y. (2013), "A cross cultural study of antecedents on career preparation behavior: Learning motivation, academic achievement, and career decision self-efficacy", Journal of Hospitality, Leisure, Sport \& Tourism Education, Vol. 13, pp. 19-32.

Chuang, N-K. and Dellmann-Jenkins, M. (2010), "Career decision making and intention: A study of hospitality undergraduate students", Journal of Hospitality \& Tourism Research, Vol. 34 No. 4, pp. 512-530.

Chung, Y.B. (2002), "Career decision-making self-efficacy and career commitment: Gender and ethnic differences among college students", Journal of Career Development, Vol. 28 No. 4, pp. 277-284. 
Cole, A.B. and Knowles, J. (2001), "What is life history research?", in Cole, A.B. and Knowles, J. (Eds.), Live in the Context: The Art of Life History Research, Altamira, Walnut Creek, pp. 924.

Collin, A. and Young, R.A. (2000), "The future of career", in Collin, A. and Young, R.A. (Eds.), The Future of Career, Cambridge University Press, Cambridge, pp. 276-300.

Creswell, J.W. (2007), Qualitative Inquiry \& Research Design: Choosing among Five Approaches, 2nd Edition, Sage, Thousand Oaks.

Cropanzano, R. and Mitchell, M.S. (2005), "Social exchange theory: An interdisciplinary review", Journal of Management, Vol. 31 No. 6, pp. 874-900.

Davidson, M.C.G., McPhail, R. and Barry, S. (2010), “Hospitality HRM: Past, present and the future", International Journal of Contemporary Hospitality Management, Vol. 23 No. 4, pp. 498-516.

Deery, M. and Jago, L. (2015), "Revisiting talent management, work-life balance and retention strategies", International Journal of Contemporary Hospitality Management, Vol. 27 No. 3, pp.453-472.

Denzin, N.K. (1989), Interpretive Biography: Qualitative Research Methods Series 17, Sage, London.

Duarte, M.E. (2004), "O Indivíduo E a Organização: Perspectivas De Desenvolvimento. [The Individual and the Organization: Perspectives of Development]", Psychologica, (Extra-Série) pp. 549-557.

Duncan, T., Scott, D.G. and Baum, T. (2013), "The mobilities of hospitality work: An exploration of issues and debates", Annals of Tourism Research, Vol. 41, pp. 1-19.

Fouad, N.A., Kim, S., Ghosh, A., Chang, W. and Figueiredo, C. (2016), "Family influence on career decision making: Validation in India and the United States", Journal of Career Assessment, Vol. 24 No. 1, pp. 197-212.

Goodson, L. and Phillimore, J. (2004), "The inquiry paradigm in qualitative tourism research", in Phillimore, J. and Goodson, L. (Eds.), Qualitative Research in Tourism. Ontologies, Epistemologies and Methodologies, Routledge, London, pp. 30-45.

Gottfredson, L.S. (1981), "Circumscription and compromise: A developmental theory of occupational aspirations", Journal of Counselling Psychology, Vol. 28 No. 6, pp. 545-579. 
Gottfredson, L.S. (1996), "Gottfredson's theory of circumscription and compromise", in Brown, D., Brooks, L. and Associates (Eds.), Career Choice and Development, 3rd Edition, Jossey-Bass, San Francisco, pp. 179-232.

Gottfredson, L.S. (2002), "Gottfredson's theory of circumscription, comprise and selfcreation", in Brown, D. and Associates (Ed.), Career Choice and Development, 4th Edition, Jossey-Bass, San Francisco, pp. 85-148.

Gottfredson, L.S. (2005), "Applying Gottfredson's theory of circumscription and compromise in career guidance and counselling", in Brown, S.D. and Lent, R.W. (Eds.), Career Development and Counselling: Putting Theory and Research to Work, John Wiley, Hoboken, pp. 71-100.

Goodale, J.G. and Hall, D.T. (1976), "Inheriting a career: The influence of sex, values, and parents", Journal of Vocational Behavior, Vol. 8 No 1, pp. 19-30.

Goulet, L.R. and Singh, P. (2002), "Career commitment: A reexamination and an extension", Journal of Vocational Behavior, Vol. 61 No. 1, pp. 73-91.

Hackett, G. (1995), "Self-efficacy in career choices and development", in Bandura, A. (Ed.), Self-efficacy in Changing Societies, Cambridge University Press, Cambridge, pp. 232-258.

Hall, D.T. (2004), "The protean career: A quarter-century journey", Journal of Vocational Behavior, Vol. 65 No. 1, pp. 1-13.

Hancock, J.I., Allen, D.G. and Soelberg, C. (2017), "Collective turnover: An expanded metaanalytic exploration and comparison", Human Resource Management Review, Vol. 27 No. 1, pp. 61-86.

Harkison, T., Poulston, J. and Kim, J-H.G. (2011), "Hospitality graduates and managers: The big divide", International Journal of Contemporary Hospitality Management, Vol. 23 No. 3, pp. 377-392.

Hausknecht, J.P., Rodda, J. and Howard, M.J. (2009), "Targeted employee retention: performance-based and job-related differences in reported reasons for staying", Human Resource Management, Vol. 48 No. 2, pp. 269-288.

Hodkinson, P. (2008), "Understanding career decision-making and progression: Careership revisited", NICEC John Killeen Memorial Lecture 2008 Woburn House, London. 
Hodkinson, P. and Sparkes, A.C. (1997), "Careership: A sociological theory of career decision making", British Journal of Sociology of Education, Vol. 18 No. 1, pp. 29-44.

Horng, J.S. and Lin, L. (2013), "Training needs assessment in a hotel using 360 degree feedback to develop competency-based training programs", Journal of Hospitality and Tourism Management, Vol. 20, pp. 61-67.

Inkson, K. (2004), "Images of career: Nine key metaphors", Journal of Vocational Behavior, Vol. 65 No. 1, pp. $96-111$

Inkson, K. (2007), Understanding Careers: The Metaphors of Working Lives, Sage, London.

Johns, N. and McKechnie, M. (1995), "Career demands and learning perceptions of hotel and catering graduates- ten years on", International Journal of Contemporary Hospitality Management, Vol. 7 No. 5, pp. 9-12.

Karatepe, O.M. (2013), "High-performance work practices and hotel employee performance: the mediation of work engagement", International Journal of Hospitality Management, Vol. 32, pp. 132-140.

Khapova, S.N. and Arthur, M.B. (2011), "Interdisciplinary approaches to contemporary career studies", Human Relations, Vol. 64 No. 1, pp. 3-17.

Kim, B., McCleary, K.W. and Kaufman, T. (2010), "The new generation in the industry: Hospitality/tourism students' career preferences, sources of influence and career choice factors", Journal of Hospitality and Tourism Education, Vol. 22 No. 3, pp. 5-11.

King, B., McKercher, B. and Waryszak, R. (2003), "A comparative study of hospitality and tourism graduates in Australia and Hong Kong", International Journal of Tourism Research, Vol. 5 No. 6, pp. 409-420.

Ko, W. (2007), "Training, satisfaction with internship programs, and confidence about future careers among hospitality students: A case study of universities in Taiwan", Journal of Teaching in Travel and Tourism, Vol. 7 No. 4, pp. 1-15.

Ladkin, A. (2004), "The life and work history methodology: A discussion of its potential use for tourism and hospitality research", in Phillimore, J.A. and Goodson, L. (Eds.), Qualitative Research in Tourism: Ontologies, Epistemologies, Methodologies, Routledge, London, pp. 236-254. 
Leung, S.A. (2008), "The Big Five career theories", in Athanasou, J.A. and van Esbroeck, R. (Eds.), International Handbook of Career Guidance, Springer, London, pp. 115-132.

McKercher, B., Williams, A. and Coghlan, I. (1995), "Career progress of recent tourism graduates", Tourism Management, Vol. 16 No. 7, pp. 541-545.

Meyer, J.P. and Allen, N.J. (1984), "Testing the "Side-Bet Theory" of organizational commitment: Some methodological considerations", Journal of Applied Psychology, Vol. 69 No. 3, pp. 372-378.

Meyer, J.P., Allen, N.J. and Smith, C.A. (1993), "Commitment to organizations and occupations: Extension and test of a three-component conceptualization", Journal of Applied Psychology, Vol. 78 No. 4, pp. 538-551.

Meyer, J.P. and Herscovitch, L. (2001), "Commitment in the workplace: Toward a general model", Human Resource Management Review, Vol. 11 No. 3, pp. 299-326.

Meyer, J.P., Stanley, D.J., Herscovitch, L. and Topolnytsky, L. (2002), "Affective, continuance, and normative commitment to the organization: A meta-analysis of antecedents, correlates, and consequences", Journal of Vocational Behavior, Vol. 61 No. 1, pp. 20-52.

Miller, R.L. (2000), Researching Life Stories and Family Histories, Sage, London.

Niu, H-J. (2010), "Investigating the effects of self-efficacy on foodservice industry employees' career commitment", International Journal of Hospitality Management, Vol. 29 No. 4, pp. 743-750.

O'Leary, S. and Deegan, J. (2005), "Career progression of Irish tourism and hospitality management graduates", International Journal of Contemporary Hospitality Management, Vol. 17 No. 5, pp. 421-432.

Patton, W. and McMahon, M. (2006), Career Development and Systems Theory, 2nd Edition, Sense Publishers, Rotterdam.

People $1^{\text {st }}$ (2017), Migrant workers in the hospitality and tourism sector and the potential impact of labour restrictions, People $1^{\text {st }}$, London.

Rehman, N. and Mubashar, T. (2017), "Job stress, psychological capital and turnover intentions in employees of hospitality industry", Journal of Behavioural Sciences, Vol. 27 No. 2, pp. 59-79. 
Richardson, S. (2009), "Undergraduates' perceptions of tourism and hospitality as a career choice", International Journal of Hospitality Management, Vol. 28 No. 3, pp. 382-388.

Salihoğlu, G. and Gezici, F. (2018), "Geography of suppliers in the hospitality sector: The case of Alanya", Tourism Management, Vol. 65, pp. 41-54.

Savickas, M.L., Nota, L., Rossier, J., Dauwalder, J-P., Duarte, M.E., Guichard, J., Soresi, S., Van Esbroeck, R. and van Vianen, A.E.M. (2009), "Life designing: A paradigm for career construction in the 21st century", Journal of Vocational Behavior, Vol. 75 No. 3, pp. 239-250

Severt, D., Aiello, T., Elswick, S. and Cyr, C. (2008), "Hospitality in hospitals?", International Journal of Contemporary Hospitality Management, Vol. 20 No. 6, pp. 664-678.

Sewell, W.J. (1992), "A theory of structure: Duality, agency and transformation", The American Journal of Sociology, Vol. 98 No. 1, pp. 1-29.

Sullivan, S.E., Carden, W.A. and Martin, D.F. (1998), "Careers in the next millennium: Directions for future research", Human Resource Management Review, Vol. 8 No. 2, pp. 165-185.

Sullivan, S.E. and Baruch, Y. (2009), "Advances in career theory and research: A critical review and agenda for future exploration", Journal of Management, Vol. 35 No. 6, pp. 15421571.

Saunders, B., Sim, J., Kingstone, T., Baker, S., Waterfield, J., Bartlam, B., Burroughs, H. and Jinks, C. (2018), "Saturation in qualitative research: exploring its conceptualization and operationalization", Quality \& Quantity, Vol. 52 No. 4, pp. 1893-1907.

Swanson, J.L. and Fouad, N.A. (2010), Career Theory and Practice: Learning through Case Studies, 2nd Edition, Sage, London.

Telfer, E. (2000), "The philosophy of hospitableness", in Lashley, C. and Morrison, A. (Eds.), In Search of Hospitality: Theoretical Perspectives and Debates, Butterworth-Heinemann, Oxford, pp. 38-55.

Usher, E.L. and Pajares, F. (2008), "Sources of self-efficacy in school: Critical review of the literature and future directions", Review of Educational Research, Vol. 78 No. 4, pp. 751-796.

Vance, R.J. (2006), Employee Engagement and Commitment: The Guide to Understanding, Measuring and Increasing Engagement in Your Organisation, SHRM Foundation, USA. 
Walsh, K. and Taylor, M.S. (2007), "Developing in-house careers and retaining management talent: What hospitality professionals want from their jobs", Cornell Hotel and Restaurant Administration Quarterly, Vol. 48 No. 2, pp. 163-182.

Warren, C.A.B. (2002), "Qualitative interviewing", in Gubrium, J.F. and Holstein, J.A. (Eds.), Handbook of Interview Research: Context and Method, Sage, Thousand Oaks, pp. 83-101.

Weber, K. and Ladkin, A. (2008), "Career advancement for tourism and hospitality academics: Publish, network, study, and plan", Journal of Hospitality \& Tourism Research, Vol. 32 No. 4, pp. 448-466.

Weiss, J.W., Skelley, M.F., Haughey, J.C. and Hall, D.T. (2003), "Calling, new careers and spirituality: A reflective perspective for organizational leaders and professionals", in Pava, M.L. and Primeaux, P. (Eds.), Spiritual Intelligence at Work: Meaning, Metaphor, and Morals (Research in Ethical Issues in Organizations, Volume 5), Emerald Group Publishing Limited, pp. 175-201.

Wildes, V.J. (2005), "Stigma in food service work: How it affects restaurant servers' intention to stay in the business or recommend a job to another", Tourism and Hospitality Research, Vol. 5 No. 3, pp. 213-233.

WTTC (World Travel and Tourism Council) (2017), Travel and Tourism Economic Impact 2017, WTTC, London.

Yang, J. , Wan, C. and Fu, Y. (2012), "Qualitative examination of employee turnover and retention strategies in international tourist hotels in Taiwan", International Journal of Hospitality Management, Vol. 31 No. 3, pp. 837-848.

Appendix 1. Participants' Profiles 
Figure 1. The leaving process PATTERN 2

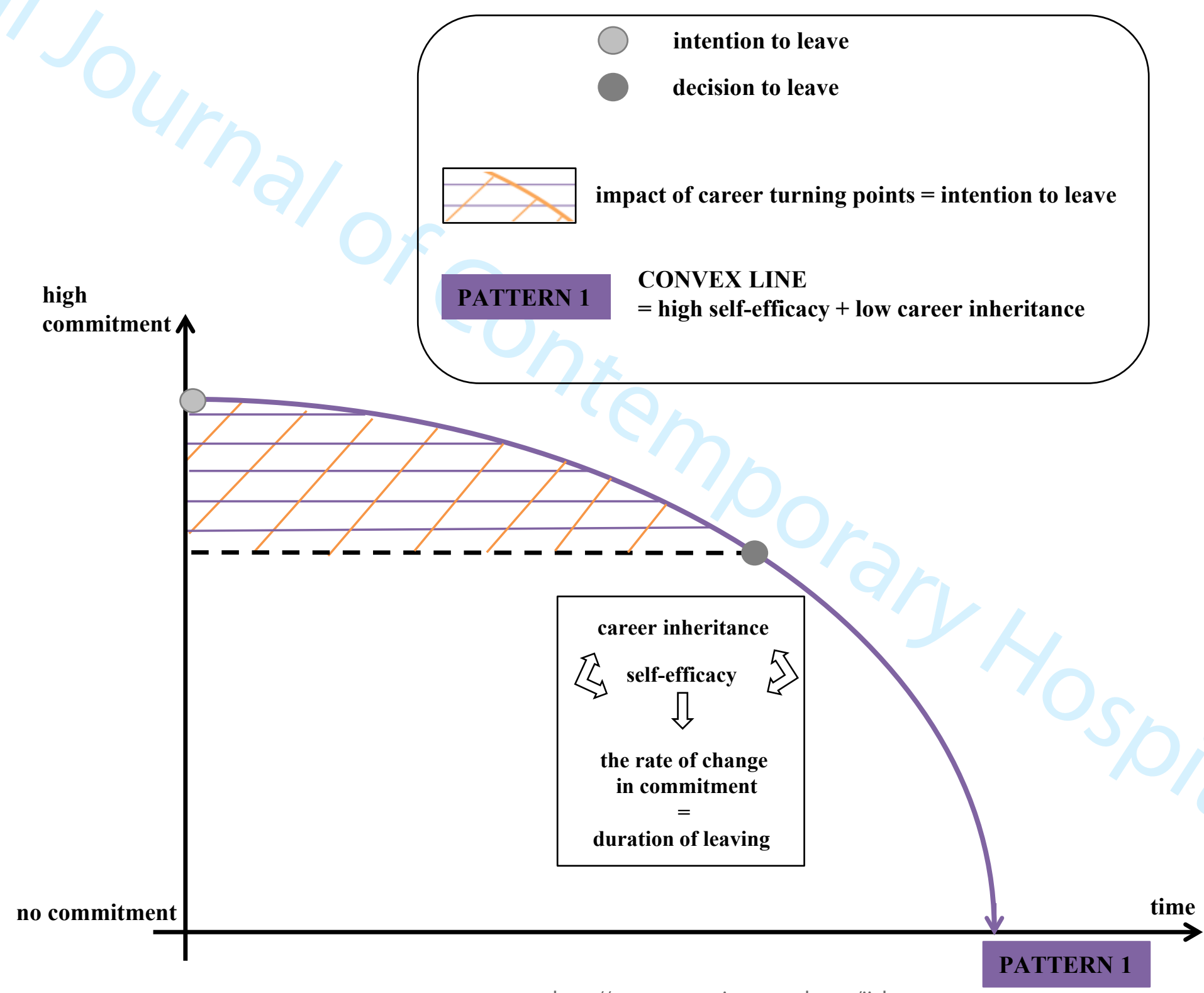

http://mc.manuscriptcentral.com/ijchm 
Figure 2. The leaving process PATTERN 2

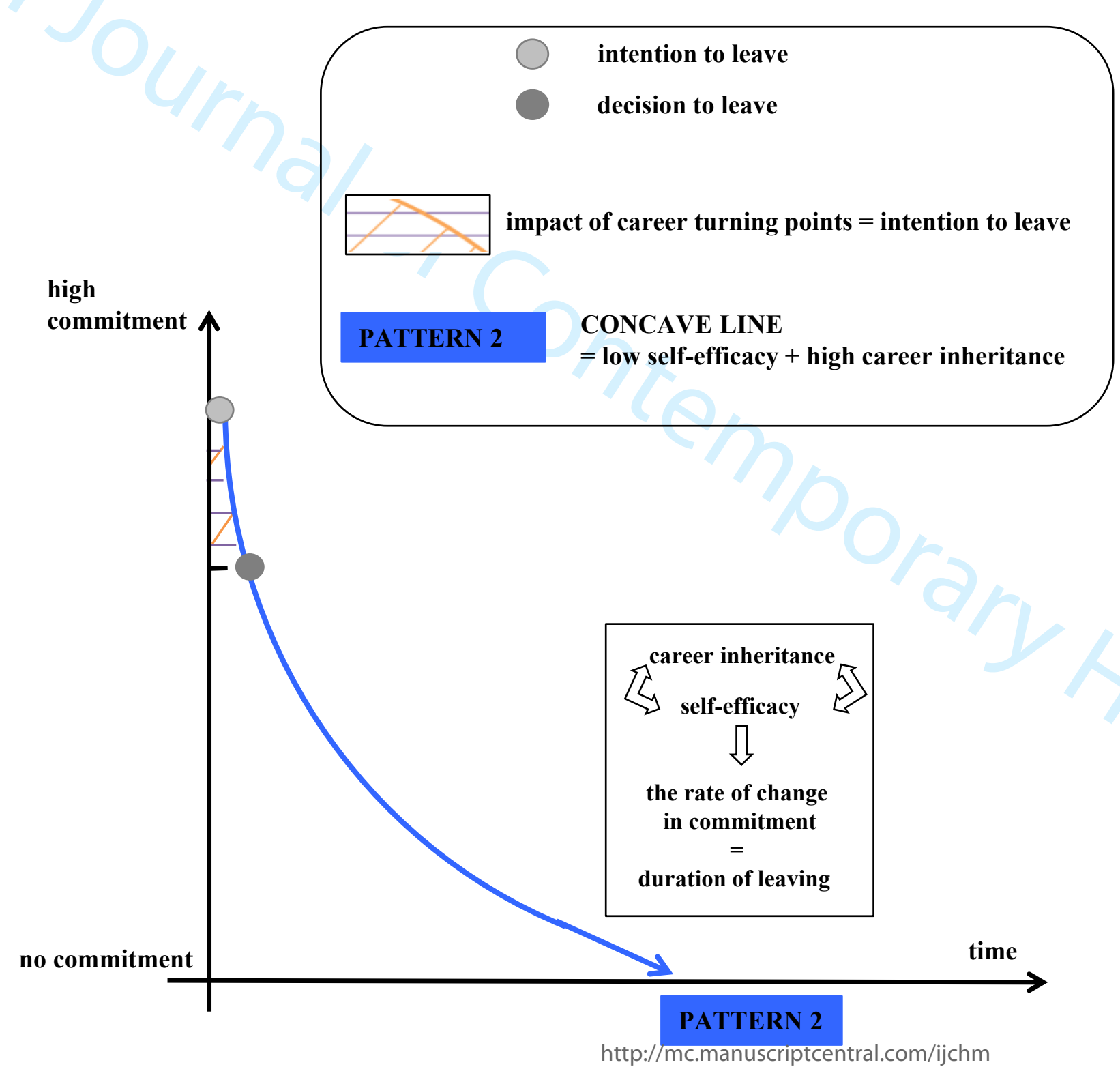


Figure 3. The leaving process PATTERN 3

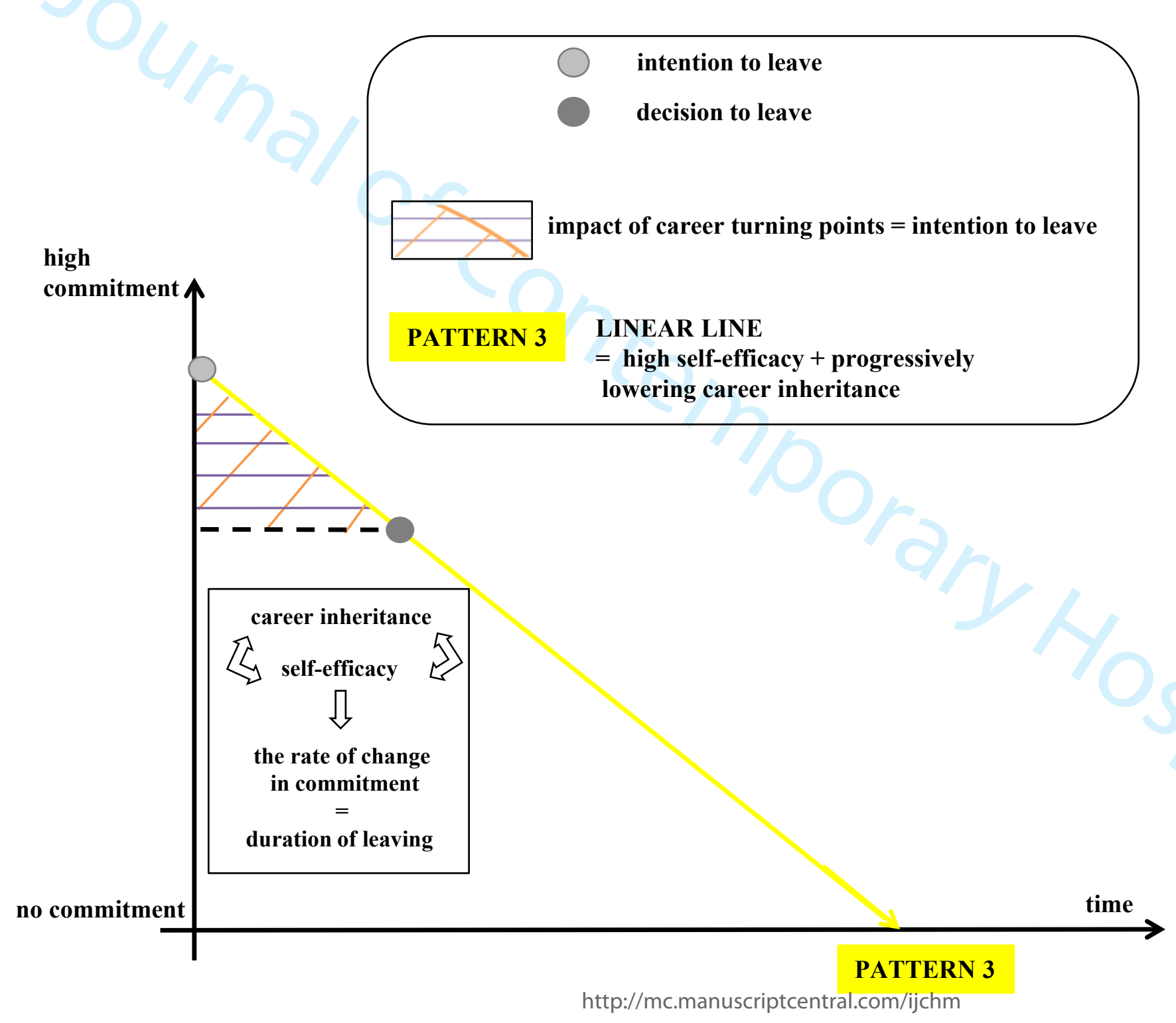




\section{Figure 4. The Leaving Process}

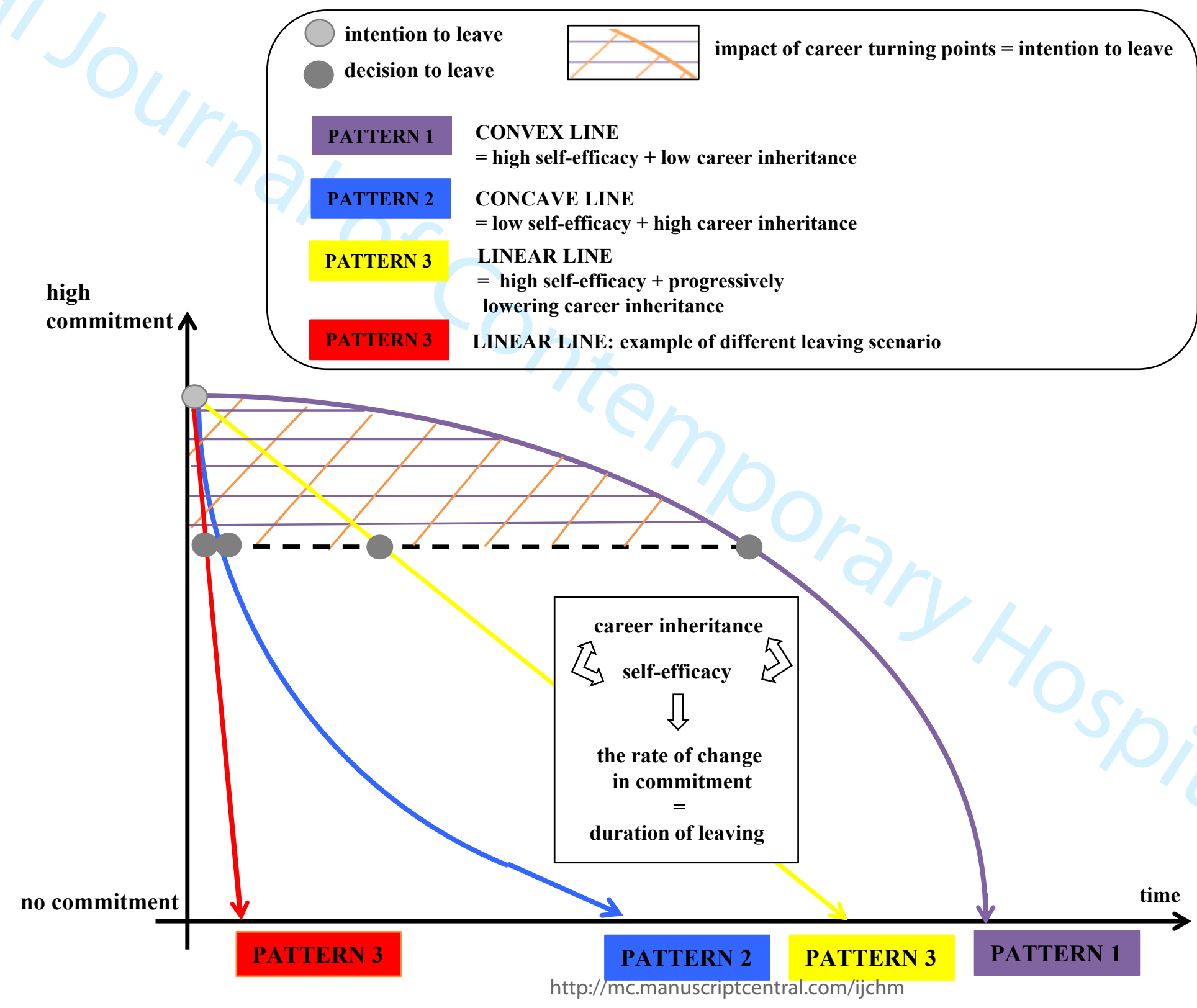

